\title{
(2) OPEN ACCESS \\ Atypical chest pain in a young woman with an interatrial bronchogenic cyst
}

\author{
Essam Saad 지, Pooja Singh, Marc Iskandar
}

Department of Internal Medicine, Advocate Illinois Masonic Medical Center, Chicago, Illinois, USA

\section{Correspondence to \\ Dr Essam Saad;} essam.saad@aah.org

Accepted 6 April 2021

\section{Check for updates}

(c) BMJ Publishing Group Limited 2021. Re-use permitted under CC BY-NC. No commercial re-use. See rights and permissions. Published by BMJ.

To cite: Saad E, Singh $P$, Iskandar M. BMJ Case Rep 2021;14:e241736. doi:10.1136/bcr-2021241736

\section{SUMMARY}

A 31-year-old woman presented to the emergency department with atypical retrosternal chest pain and dyspnoea. Investigations initially revealed atrial flutter on her electrocardiogram and an interatrial septal mass on CT angiography of the chest. Additional workup with cardiac MRI and transoesophageal echocardiogram were able to delineate the cardiac mass. Electrophysiology and cardiothoracic surgery were consulted. The mass was excised in the same hospitalisation and the pathology report demonstrated a bronchogenic cyst. After mass excision, the patient chest pain has decreased, and she reverted back to normal sinus rhythm. On further followup, her flecainide and metoprolol were stopped.

\section{BACKGROUND}

Bronchogenic cysts are congenital anomalies that originate from the primitive ventral foregut.

These cysts usually contain mucoid material and are lined by ciliated columnar or cuboidal epithelium. The most common locations are mediastinal, intrapulmonary or in the lower neck.

Patients are usually asymptomatic, but symptomatic patients usually present with cough and chest pain. A less common but dramatic manifestation might include respiratory distress, stridor and hypoxia from airway compromise. ${ }^{1}$ Intracardiac bronchogenic cysts are rare; however, when present, they are most commonly located in the interatrial septum. ${ }^{2}$ Literature review yielded various clinical presentations depending on the cyst location; this included complete heart block, dyspnoea secondary to vascular obstruction and atrial fibrillation. ${ }^{3}$ Atrial flutter is rarely found in a young patient without known cardiac history. Such a presentation warrants investigation for biological or structural causes. The management of bronchogenic cyst is usually surgical excision. ${ }^{4}$

\section{CASE PRESENTATION}

A 31-year-old woman with no medical history presented to the emergency department (ED) for atypical retrosternal chest pain and palpitations of 3 days' duration associated with mild dyspnoea. The patient had travelled to Mexico 3 months prior but reported no sick contacts. She was found to be tachycardic with a heart rate of more than $140 \mathrm{bpm}$ and the electrocardiogram showed atrial flutter with rapid ventricular response but no ischaemic changes. Chest X-ray did not show any acute changes, D-dimer in ED to evaluate for pulmonary embolism was elevated which prompted a CT angiography (CTA) of the chest, revealing a
5.6 (medio-lateral) $\times 5.5 \quad$ (superio-inferior $) \times 5.2$ (antero-posterior) $\mathrm{cm}$ soft tissue density along the interatrial septum. Electrophysiology and cardiothoracic surgery were consulted for further management.

A transthoracic echocardiogram (TTE) failed to visualise or characterise the mass but showed an intra-atrial septal defect later clarified to be a patent foramen ovale (PFO). An MRI of the heart was obtained and showed a rare protein-containing intracardiac cyst within the left atrium, along the interatrial septum (figure 1). Transoesophageal echocardiogram (TEE) was done to help delineate the type of the mass, define anatomic attachment to the septum, presence or absence of flow in and out of the mass, as well as mass effect on the left atrial and inferior vena cava haemodynamics which were not well defined on TTE or MRI, confirmed the cyst location to be on the left atrial side of the septum and partially abutting into the right atrium without a haemodynamic compromise.

Patient's arrhythmia was resistant to flecainide, diltiazem, and multiple rate and rhythm control measures. In the light of the impressive size, arrhythmic effect and possible pending haemodynamic obstruction, the patient underwent subtotal resection of the cyst with a portion of the cyst cavity wall remaining attached to the outside of the left atrium as there was a concern of atrial wall damage with full resection. The cyst contained yellow fluid that was sent to pathology. Final pathology report demonstrated a benign inflamed bronchogenic cyst (figure 2).

\section{OUTCOME AND FOLLOW-UP}

The patient remained on flecainide and metoprolol with no recurrence of arrhythmia since discharge. After 2 months of being symptom free, she followed up with the electrophysiology clinic where both of her medications were stopped, and she remained in normal sinus rhythm.

\section{DISCUSSION}

Our case is one of the largest documented intraatrial bronchogenic cysts measuring as noted in excess of $5 \mathrm{~cm}$. Typical of this type of cardiac cyst, presentation was in the setting of a sustained episode of dyspnoea and palpitations representing a first diagnosis of arrhythmia, in this case atypical flutter and subsequent atrial fibrillation with rapid ventricular response, although mass effect causing an obstruction of blood flow can be the cause of the symptoms. The patient did admit to multiple lifetime episodes of such 


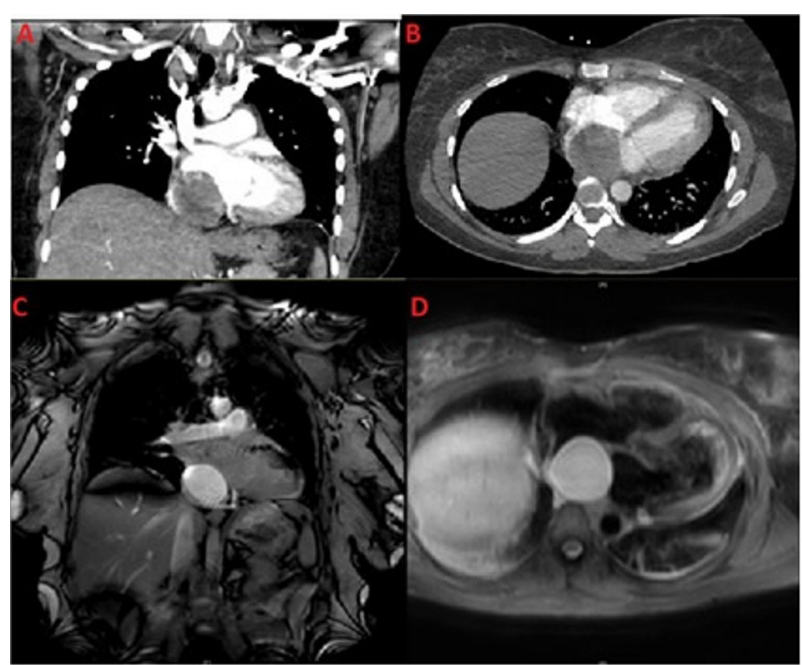

Figure 1 Panels (A) and (B) show CT angiography of the chest findings. Panels (C) and (D) show cardiac MRI findings.

symptoms but most short lived. In this case, arrhythmic management for this atypically young patient was challenging and unresponsive to combination of flecainide and diltiazem. Physical examination did not note tumour plop or other abnormal auscultatory findings of concern.

The investigation of pulmonary embolism led to the identification of an impressively large mass located in the left atrium with partial abutting into the right atrium, leaving overall cardiac chamber sizes at the upper limit of normal. The location of the cyst being in the interatrial septum was missed on transthoracic imaging; instead, cardiac MRI and TOE were more reliable in anatomic and haemodynamic significance, respectively. MRI allowed narrowing down the differential to a cystic structure due to the fluid-filled anatomy. TOE better delineated the intra-atrial septal anatomy and identified an underlying left to right intra-atrial shunt with unknown significance as it was directly overlayed by the cyst preventing proper evaluation of flow and haemodynamics. Despite its large size, the cyst was found to be minimally mobile likely preventing significant tumour plop, murmur or left atrial enlargement. This may explain the lack of significant noticeable lifelong haemodynamic-related

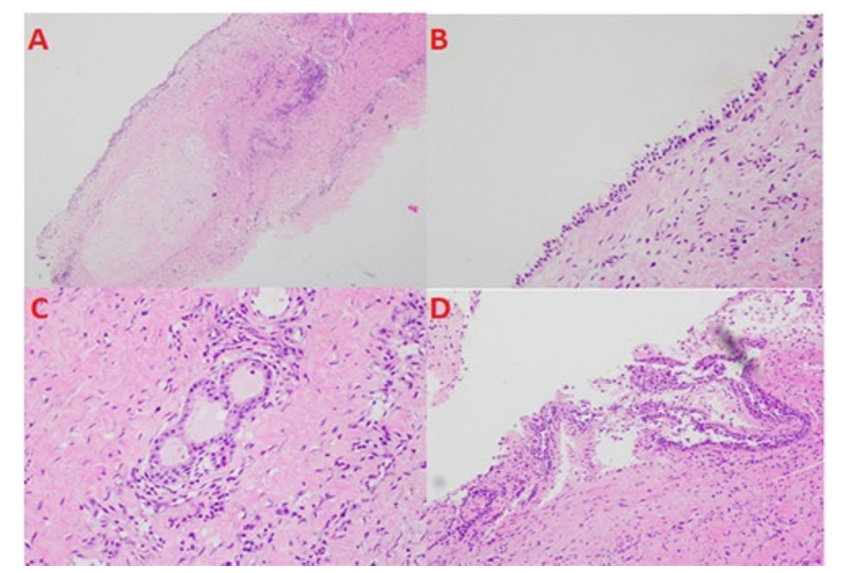

Figure 2 Pathological images of intra-atrial cyst content. Panel (A) shows hyaline cartilage and chronic inflammatory cells; panel (B) shows cyst wall with serous glands; panel (C) exhibits cyst wall lined by benign ciliated epithelium; and panel (D) shows the benign ciliated epithelium. symptoms resulting in the initial presentation to mainly be triggered by this likely mass provoked atrial flutter and fibrillation.

Surgical evaluation revealed a large cyst adherent to the left atrial wall without exposing endocardium. Due to possibility of infectious aetiology, the cyst was carefully drained resulting in $80 \mathrm{~mL}$ of turbid fluid, irrigated with hypertonic saline and due to the overlaying of the cyst with the wall, the cyst was partially resected leaving a small part of the cyst wall to avoid the complication of causing a heart block. A PFO was also noted but not closed to avoid the risk of atrial fibrillation as a complication of PFO closure in the future and as there is no clinical indication for closure.

Histopathological evaluation confirmed pseudo-striated ciliated epithelium with focal squamous metaplasia, smooth muscle bundles. Hyaline cartilage with reactive fibrosis, mesothelial cell proliferation and mixed inflammatory cell infiltrates are highly characteristic of bronchogenic cyst. Immunostaining for smooth muscle action, calretinin, CD 68, synaptophysin, S100 represents muscle bundles, mesothelial cells, macrophages and ganglion cells, respectively. The noted profile supports diagnosis of bronchogenic cyst and cytology of the fluid and cyst did not reveal any neoplastic aetiology. Of note, brief review of literature reported instances of intracardiac cysts associated with neoplasms despite its likely embryologic aetiology. In our case, screening revealed multiple hepatic adenomas all $<5 \mathrm{~cm}$, which we recommended periodic surveillance. Follow-up at 3 and 5 years of surgery as mentioned in other case reports showed no recurrence of the tumour. ${ }^{5}$

\section{Learning points}

Atrial flutter is a rare diagnosis in the younger population; it requires extensive evaluation to identify anatomical or genetic pathology as an aetiology.

- Transthoracic echocardiogram may fail to clearly visualise an intra-atrial mass; transoesophageal echocardiogram and MRI are effective modalities of imaging to evaluate such masses.

- Identification of an intra-atrial cyst on MRI following foreign travel raises a significant possibility of hydatid disease.

- The possibility of an infective origin of an intra-atrial cyst necessitates a careful surgical approach with aspiration of fluid before excision and irrigation with hypertonic saline.

- Although malignant transformation is possible in bronchogenic cysts, the extent of the excision margin should be limited to minimise the risk of iatrogenic complete heart block that would have necessitate the implantation of a permanent pacemaker.

Contributors ES: Wrote the summary and case presentation. PS: Looked up relevant articles and wrote the background. MI: Wrote the discussion and learning points.

Funding The authors have not declared a specific grant for this research from any funding agency in the public, commercial or not-for-profit sectors.

Competing interests None declared.

Patient consent for publication Obtained.

Provenance and peer review Not commissioned; externally peer reviewed.

Open access This is an open access article distributed in accordance with the Creative Commons Attribution Non Commercial (CC BY-NC 4.0) license, which permits others to distribute, remix, adapt, build upon this work non-commercially, and license their derivative works on different terms, provided the original work is properly cited and the use is non-commercial. See: http://creativecommons.org/ licenses/by-nc/4.0/. 
ORCID iD

Essam Saad http://orcid.org/0000-0002-6657-3720

\section{REFERENCES}

1 Berrocal T, Madrid C, Novo S, et al. Congenital anomalies of the tracheobronchial tree, lung, and mediastinum: embryology, radiology, and pathology. Radiographics 2004;24:e17.
2 Vaideeswar P, Agnihotri MA, Patwardhan AM. Intracardiac bronchogenic cyst. J Card Surg 2011;26:266-8.

3 Borges AC, Knebel F, Lembcke A, et al. Bronchogenic cyst of the interatrial septum presenting as atrioventricular block. Ann Thorac Surg 2009:87:1920-3.

4 Patel SR, Meeker DP, Biscotti CV, et al. Presentation and management of bronchogenic cysts in the adult. Chest 1994;106:79-85.

5 Jiang $\mathrm{H}$, Wang $\mathrm{H}, \mathrm{Wu} \mathrm{H}$, et al. Bronchogenic cyst of the interatrial septum. J Cardiothorac Surg 2013;8:171.

Copyright 2021 BMJ Publishing Group. All rights reserved. For permission to reuse any of this content visit https://www.bmj.com/company/products-services/rights-and-licensing/permissions/

BMJ Case Report Fellows may re-use this article for personal use and teaching without any further permission.

Become a Fellow of BMJ Case Reports today and you can:

- Submit as many cases as you like

- Enjoy fast sympathetic peer review and rapid publication of accepted articles

- Access all the published articles

- Re-use any of the published material for personal use and teaching without further permission

Customer Service

If you have any further queries about your subscription, please contact our customer services team on +44 (0) 2071111105 or via email at support@bmj.com.

Visit casereports.bmj.com for more articles like this and to become a Fellow 